\title{
The Horrors of War in the History of German Literature: From Heinrich Wittenwiler and Hans Jacob Christoffel von Grimmelshausen to Rainer Maria Remarque
}

\author{
By Albrecht Classen*
}

\begin{abstract}
As terrible as wars have always been, for the losers as well as for the winners, considering the massive killings, destruction, and general horror resulting from it all, poets throughout time have responded to this miserable situation by writing deeply moving novels, plays, poems, epic poems, and other works. The history of Germany, above all, has been filled with a long series of wars, but those have also been paralleled by major literary works describing those wars, criticizing them, and outlining the devastating consequences, here disregarding those narratives that deliberately idealized the military events. While wars take place on the ground and affect people, animals, objects, and nature at large, poets have always taken us to imaginary worlds where they could powerfully reflect on the causes and outcomes of the brutal operations. This paper takes into view some major German works from the early fifteenth through the early twentieth century in order to identify a fundamental discourse that makes war so valuable for history and culture, after all. Curiously, as we will recognize through a comparative analysis, some of the worst conditions in human history have produced some of the most aesthetically pleasing and most meaningful artistic or literary texts. So, as this paper will illustrate, the experience of war, justified or not, has been a cornerstone of medieval, early modern, and modern literature. However, it is far from me to suggest that we would need wars for great literature to emerge. On the contrary, great literature serves as the public conscience fighting against wars and the massive violence resulting from it.
\end{abstract}

\section{War and Literature: A Paradoxical Correlation, Past and Present}

While medieval poets tended to present rather glorious images of war because the knights could gain much glory in the fighting, already writers in the late Middle Ages realized a significant paradigm shift. In the early fifteenth century, for instance, the Constance public notary Heinrich Wittenwiler wrote a most curious allegorical verse narrative, Der Ring, in which we are confronted with the world of peasants who do not know how to operate rationally and so quickly turn to violence, which then explodes into a war in which the entire population of the village Lappenhausen is decimated. Wittenwiler's text might have been too apocalyptic or too foresightful for its time, since it has survived in only one manuscript. Quantity of text transmission, however, is not necessarily a good benchmark to determine the quality of a literary work, as we know from numerous examples in medieval literature.

"Distinguished Professor, University of Arizona, USA. 
The situation was already very different in the seventeenth century when Christopher von Grimmelshausen created his basically anti-war novel Simplicissimus (1668), reacting to the consequences of the Thirty Years' War (1618-1648). This novel became so popular that many translations and adaptations in other European languages appeared in print. Here we encounter brutal images of war and destruction affecting an entire world, all embedded in a biographical framework. Finally, this paper will address Erich Maria Remarque's Im Westen nichts Neues (1928/1929) in which the horrors of the First World War gain tremendous profile from the perspective of its protagonist, Paul Bäumer.

Although these three literary masterpieces differ in many ways from each other, at a closer analysis we discover how much the terror of war can also produce outstanding literary works of a similar kind throughout time. Even though Wittenwiler's narrative did not enjoy any significant popularity (one manuscript only), he addressed the very same issue as Remarque ca. 600 years later, and so belongs to the same tradition of, simply put, anti-war literature.

On the one hand, there is the horror of war, with its endless suffering and massive deaths, on the other, there are poets who have raised their voices throughout time and assumed the highly ennobling function of turning into their people's or nations' consciousness. On the other, and rather oddly, war, as terrible as it has always been, at least as perceived by the victims, has thus also served as a catalyst for some of the best or most effective literary products, that is, fictional texts, poems, art works, movies, and sculpture in which sharp and poignant criticism of war could be formulated.

The history of mankind has almost always been determined by war, if we think of the war between the Greeks and the Trojans, which Homer described so powerfully in his Iliad, then of the medieval crusades, which countless chroniclers and poets mirrored in their works, thereupon the Thirty Years' War, probably best documented by the famous German Baroque poet Christopher von Grimmelshausen, or the First World War, which Erich Maria Remarque documented in a most gruesome and despondent manner.

The Napoleonic wars found their probably most vivid spokesperson in Leo Tolstoy when he wrote his War and Peace, published in 1869. Stephen Crane's The Red Badge of Courage (1895) ominously mirrored the American Civil War (18611865); Ernest Hemingway's A Farewell to Arm dramatized, if not idealized, his experiences in World War I (1914-1918), which found a stunning parallel in Ernst Jünger's In Stahlgewittern (1920); and Tim O'Brien documented with his The Things They Carried (1990) the Vietnam War (1955-1975). The Second World War (1939-1945) was reflected, from an American perspective, in countless works, such as Evelyn Waugh's Put Out More Flags (1942), Henry Green's Caught (1943), James Hanley's No Directions (1943), Patrick Hamilton's The Slaves of Solitude (1947), and Elizabeth Bowen's The Heat of the Day (1949), which was richly matched by German contributions, such as Walter Kempowski's Das Echolot Abgesang ' 45 (2005). To this we could add a long list of works in many European 
languages, and then widen the perspective and incorporate world literature from throughout time because no country, no culture, no religion, and no language group has ever lived without experiencing military conflicts.

Tragically, the world has witnessed countless more wars since 1945, but this has not daunted writers all over the world to respond in kind, criticizing, debating, idealizing, and questioning war itself. We are facing almost a kind of ying/yang in terms of war, as some of the worst experiences of people-in warhave produced some of the best forms of literary reflections and imaginations. This phenomenon has been a global one, whether we turn our attention to Japanese, Chinese, Australian, Nigerian, or Argentinian literature. The present paper aims at a critical analysis of the fictional discourse on war in the history of German literature from the late Middle Ages to the 1920s, not in order to offer a comprehensive overview, which would be impossible at any rate, but with the purpose of unearthing the fundamental function of literature itself to come to terms with human suffering and the ability to rally enough resolve to fight the consequences and impact of war on human life and to find a way out of the horrors of military operations.

\section{Poets against War: The Literary Protest against Barbarity against Humankind}

It would not be difficult to find much literature from throughout time in which wars were glorified as the struggle of the fittest against the weaker ones, as a triumphal effort to resist an evil or outside force, or as a medium for the male protagonist to prove his, sometimes also her, heroic accomplishments and achievements defending the own people or country. Ancient, medieval, and modern heroic literature illustrates this phenomenon impressively, and then, quite understandably in light of the specific genre criteria, only questions regarding guilt, innocence, honor, and power matter (Homer's Iliad, Beowulf, Le Chanson de Roland, Nibelungenlied, El poema de mío Cid, etc.) ${ }^{1}$ Nevertheless, the critical voices against war have traditionally received a much higher level of recognition amongst scholars (and readers?), representing deep challenges against the military and economic powers and the social and religious establishments. The public readership, however, might have preferred texts that have promoted war, after all, if we consider the world of bestsellers glorifying war ${ }^{2}$. War and all

1. David Konstan and Kurt A. Raaflaub (Eds.), Epic and History. The Ancient World: Comparative Histories (Maldon, MA, and Oxford: Blackwell, 2010).

2. For many cases in modern literature, see Samuel Hyne, On War and Writing (Chicago and London: The University of Chicago Press, 2018); cf. also Alex Houen and Jan-Melissa Schramm (Eds.), Sacrifice and Modern War Literature: From the Battle of Waterloo to the War on Terror (Oxford: Oxford University Press, 2018); Hélène Baty-Delalande and 
related military operations have always challenged people deeply as to their ethical, moral, religious, political, and economic justifications, especially on the side of the losers, whereas the victors have, of course, tendentiously basked in the glory of their accomplishments - vae victis, as the Romans used to say, here not counting, tragically, the millions of dead soldiers.

Overall, most literary texts produced throughout time have focused primarily on just a short list of universal topics, such as love and death, God and the meaning of life, the quest for truth, and then, most ominously, on war. ${ }^{3}$ Insofar as war with its massive killing of soldiers and also civilians has always had a deeply traumatic impact on the survivors, irrespective of the outcome for either side, it is quite understandable that the poetic voices have regularly focused on this issue. ${ }^{4}$ This fact then allows us to embark on a critical discussion of three masterpieces in German literature where war assumes a central role and is viewed in most critical terms. Each work has already been discussed from many different perspectives, but they all can be identified as major contributions to one and the same discourse and thus deserve to be examined in connection with each other. With respect to military actions throughout time, previous literary-historical research has commonly focused on one century, on one major war, particularly World War I and II, whereas here I will bring together poetic comments from the late

Maxime Decout (Eds.), Écrits de guerre: laboratoires esthétiques. Revue de Sciences Humaines, 326 (Villeneuve d'Ascq: Septentrion, 2017); Jörg Rogge (Ed.), Kriegserfahrungen erzählen: Geschichts- und literaturwissenschaftliche Perspektiven. Mainzer historische Kulturwissenschaften, 37 (Bielefeld: transcript, 2017). For war literature in Nazi Germany, see Gerrit Lungershausen, Weltkrieg mit Worten: Kriegsprosa im Dritten Reich 1933 bis 1940 (Wiesbaden: J. B. Metzler, 2017). But every war has triggered the production of its own literary responses, supporting or opposing the efforts by the individual war parties.

3. For a useful overview, see Ursula Homann, Der Krieg in der Literatur. Retrieved from: http://www.ursulahomann.de/DerKriegInDerLiteratur/kap001.html; famous Erich Auerbach also offered most insightful reflections and a survey in his essay "Literatur und Krieg," Erich Auerbach, Kultur als Politik: Aufsätze aus dem Exil zur Geschichte und Zukunft Europas (1938-1947), ed. Christian Rivoletti (Constance: Konstanz University Press, 2014), here quoted from the online version at: https://faustkultur.de/2025-0-Auerbach-Literaturund-Krieg.html); see also Manuel Mackasare, "Krieg und Literatur," akademische Blätter. Retrieved from: https://aka-blaetter.de/krieg-und-literatur/. He focuses, however, only on Ernst Jünger, Walter Flex, and Erich Maria Remarque, all reflecting the First World War. See now the survey by Catherine Calloway, "War in Literature and Drama," Oxford Bibliographies Jan. 11 (2018). Retrieved from: https://bit.ly/3wWfU3d. [All Accessed March 30, 2021]

4. Christian Rohr, Ursula Bieber and Katharina Zeppezauer-Wachauer (Eds.) Krisen, Kriege, Katastrophen: Zum Umgang mit Angst und Bedrohung im Mittelalter. Interdisziplinäre Beiträge zu Mittelalter und Früher Neuzeit, 3 (Heidelberg: Universitätsverlag Winter, 2018). The contributors examine possible approaches to the topics of crises, wars, and catastrophes, using a variety of linguistic and literary data that do not necessarily concern us here. 
Middle Ages, the Baroque, and the early twentieth century (Weimar Republic), probing each time how war or military actions are described and treated in literary terms in order to reach an ethical and moral assessment.

In the volume entitled War and Literature, ed. by Laura Ashe and Ian Patterson, "the contributors reflect on the uneasy yet symbiotic relations of war and writing, from medieval to modern literature. War writing emerges in multiple forms, celebratory and critical, awed and disgusted; the rhetoric of inexpressibility fights its own battle with the urgent necessity of representation, record and recognition. This is shown to be true even to the present day: whether mimetic or metaphorical, literature that concerns itself overtly or covertly with the real pressures of war continues to speak to issues of pressing significance, and to provide some clues to the intricate entwinement of war with contemporary life. ${ }^{5 \prime \prime}$

In fact, scholarship has intensively researched this huge topic, offering many different perspectives on equally many texts and art works from throughout time. ${ }^{6}$ But how have writers mirrored the dimension of fear, abhorrence, disgust, and hence how have they formulated concluding concepts about the danger of war in an apocalyptic context? My approach here is focused on those three major works in German literature where the consequences of massive killing in war is profiled in a rather alarming fashion. I do not want to pursue a close reading of each individual text because this would easily lead us astray, getting us entangled in countless details and would probably not yield truly new insights. After all, Wittenwiler's verse romance, Der Ring (ca. 1400), Grimmelshausen's Simplicissimus (1669), and Erich Maria Remarque's Im Westen nichts Neues (1929) have already been examined, each by itself, by numerous literary scholars both in the Germanspeaking world and far beyond. We can easily confirm that they all represent literary accomplishments of the first rank, as the large number of critical studies confirms, for instance. Instead, the purpose here will be to examine more thoroughly the global perspectives toward the individual suffering in war and

5. Laura Ashe and Ian Patterson (Eds.), War and Literature. Essays and Studies, 67 (Cambridge: D. S. Brewer, 2014); the quote comes from the online page by the publisher, https://boydellandbrewer.com/9781843843818/war-and-literature/. [Accessed 30 March 2021]

6. A[rnold]. D. Harvey, A Muse of Fire: Literature, Art and War (London and Rio Grande, OH: Hambledon Press, 1998); James Dawes, The Language of War: Literature and Culture in the U.S. from the Civil War through World War II (Cambridge, MA, and London: Harvard University Press, 2002). See also the contributions to: Horst Brunner (Ed.), Der Krieg im Mittelalter und in der Frühen Neuzeit: Gründe, Begründungen, Bilder, Bräuche, Recht. Imagines medii aevi, 3 (Wiesbaden: Reichert, 1999); Horst Brunner (Ed.), Die Wahrnehmung und Darstellung von Kriegen im Mittelalter und in der Frühen Neuzeit. Imagines medii aevi, 6 (Wiesbaden: Reichert Verlag, 2000); see now Albrecht Classen and Nadia Margolis (Eds.), War and Peace: Critical Issues in European Societies and Literature 800-1800. Fundamentals of Medieval and Early Modern Culture, 8 (Berlin and New York: Walter de Gruyter, 2011). The literature on this topic is legion. 
what this experience has meant for society at large. What are the similarities and differences in the fictionalization of the drastic war situation throughout the centuries? We can be certain that here we face a universal discourse, but we still need to establish how each poet intimately approached his topic and tried to convey fundamental messages to the audience.

To put it differently, how did the individual writers respond to war, how did they translate those experiences into literary images, and how did they subsequently create new aesthetic expressions transforming the actual horror of the war into meaningful fictional messages that in turn were supposed to impact society? In particular, the central question will focus on the human suffering and the deep desire for peace expressed in each text because no war has ever sustained itself and become a raison d'être for all life, irrespective of any military triumph, as much as individual groups in society have always tried hard to pursue just that goal, such as the military-industrial complex against which President Dwight Eisenhower already warned the world about in his farewell speech on January 17, 1961 before he left office. ${ }^{7}$

There is, however, one significant difference between Wittenwiler's Ring on the one hand and the two other works. Wittenwiler did not, as far as we can tell, respond directly to any major war, despite the many military operations that took place throughout the late Middle Ages. This allegorical narrative does not contain any allusions to the past world of crusades, to the emerging threat of the Ottoman powers, or to military conflicts among the European forces, such as the Hundred Years' War between England and France (ca. 1337-1453), which raged exactly at the time when this Constance public notary composed his work. Moreover, the war that he describes erupts within the rural population, whereas the representatives of the cities all over the country wisely decide to stay out of the internal conflict.

In fact, Wittenwiler's treatment of war targets primarily the stupidity and ignorance of the protagonists whose actions trigger war, though it still outlines in highly dramatic terms the consequences of war decimating an entire village population. Grimmelshausen and Remarque, by contrast, wrote their novels under the direct influence of major wars, the former reflecting upon the consequences of the Thirty Years' War, the latter responding to the First World

7. See, for instance, Paul Koistinen, Military-Industrial Complex: A Historical Perspective (New York: Praeger, 1980); Gregg B. Walker (Ed.), The Military Industrial Complex: Eisenhower's Warning Three Decades Later. American University Studies/Series 10/Political Science, 32 (New York, San Francisco, et al.: Peter Lang, 1992); Mark H. Rose and Roger Biles (Eds.), The President and American Capitalism since 1945 (Gainesville, FL: University Press of Florida, 2017); https://www.history.com/this-day-in-history/eisenhower-warns-ofmilitary-industrial-complex; https://www.npr.org/2011/01/17/132942244/ikes-warning-ofmilitary-expansion-50-years-later; https://en.wikipedia.org/wiki/Military\%E2\%80\%93in dustrial_complex [All Accessed 30 March 2021] 
War. Nevertheless, as we will see, the outcome proves to be more or less the same in all three texts, and so the poets' messages warning about the devastating outcome of military operations emerge as strikingly parallel, all of them contributing to the same discourse that we would identify today as 'anti-war.'

Whereas the common tenor in the Middle Ages aimed at the glorification of war, whether we think of heroic epics or of crusading romances, in the late Middle Ages a profound paradigm shift affecting both the military technology and the actors on the battlefield transformed the experience of war in a radical fashion. Knighthood was increasingly outdated and could not uphold to the increasingly professionalized warfare, with the introduction of the crossbow and the longbow, and especially with the emergence of the mercenaries who subsequently gained access to the firearms that made all knighthood irrelevant. In the Hundred Years' War between England and France (1437-1553) the conditions on the ground changed radically, as best illustrated in the battle of Agincourt in 1415 when the French nobility was devastatingly crushed and decimated by a new type of army, based on mercenaries with new weapons. ${ }^{8}$

Many other wars were waged all over Europe, and this at the time when the Constance notary public Wittenwiler sat down to compose his Ring. Europeans were deeply troubled by the approaching Turks, who had beaten the Christian armies at the battle of Nicopolis in 1396, leading to the conquest of Bulgaria by the Ottomans. From 1387 to 1389, the Swabian City League waged a war against the King of Bavaria, and virtually at the same time the Swiss cantons fought bitterly against the House of Habsburg in the so-called Sempach War from 1386 to 1388. Between 1398 and 1408, the Swiss canton of Appenzell was involved in a protracted war against the abbot of St. Gall. Between 1412 and 1415 the peasants in the region of the Harz mountain fought militarily against the local nobility in the so-called Flegler War, an early predecessor of the horrible Peasant War in 1525. In fact, violent conflicts were the daily norm also of late medieval society, ${ }^{9}$ so it does not come as a surprise that Wittenwiler engaged with this topic as well, although he situates it in the world of peasants only.

Many literary texts aim for the glorification of war, as is commonly the case in medieval epics and romances, but at times, and so also in Der Ring, the fictional presentation of the horrors of war could also aim at condemning wars altogether and advocating the establishment of peace, which was, of course, primarily preached by the Church, here disregarding its vehement and consistent polemics in favor of crusades. ${ }^{10}$ The philosophical and ethical issue was always the 'just

8. Clifford J. Rogers (Ed.), "Agincourt, Battle of," The Oxford Encyclopedia of Medieval Warfare and Military Technology, volume 1 (Oxford: Oxford University Press, 2010), 7-10.

9. See the introduction by Clifford Rogers to The Oxford Encyclopedia of Medieval Warfare, xxiv-xxvi (see note 8).

10. For a global discussion of war and peace, see Irmgard Elsner Hunt, Krieg und Frieden in der deutschen Literatur; vom Barock bis heute. Europäische Hochschulschriften. Reihe 1: Deutsche Sprache und Literatur, 798 (Frankfurt a. M., Bern, and New York: Peter 
war,' and virtually every theologian struggled hard with this question since late antiquity. The poets were not far behind in that discourse. ${ }^{11}$ Not by accident, the famous Humanist Erasmus of Rotterdam (1466-1536) formulated most famously, "dulce bellum inexpertis" (war is sweet for those who have not experienced it) as the title for his essay in his Adagia (1508; repr. 1515), and thus set the tone for all subsequent participants in this global debate about the wisdom of waging wars. ${ }^{12}$

\section{Heinrich Wittenwiler's Ring}

Wittenwiler confronts us not only with a war between the residents of two villages, but he also introduces an entire rural world determined by violence. Even though this allegorical verse romance is filled with didactic texts about the proper ways to lead a decent and meaningful life, none of those teachings fulfill their purposes, and everything fails ultimately because ordinary violence breaks out during the wedding festivities and quickly erupts into a bitter war pitting two parties against each other that really share most interests, are neighbors anyway, and have come together to celebrate the wedding of a young couple, Bertschi and Mätzli. ${ }^{13}$ The two villages of Lappenhausen and Nissingen are not really justified in any of their aggressive measures, especially because the original conflict concerned only one man, Eisenbeißer (Ironbiter) who accidentally injures his

Lang 1985); Daniele Vecchiato, Krieg und Frieden in der Literatur; zu Zeugnissen aus Literatur und Publizistik der letzten drei Jahrhunderte (Berlin: "Helle Panke" e.V. - Rosa-LuxemburgStiftung Berlin 2009); Gerd Althoff, Frieden stiften: Vermittlung und Konfliktlösung vom Mittelalter bis heute (Darmstadt: Wissenschaftliche Buchgesellschaft, 2015); Katherine Ludwig Jansen, Peace and Penance in Late Medieval Italy (Princeton, NJ, and Oxford: Princeton University Press, 2018).

11. Frederick H. Russell, The Just War in the Middle Ages (Cambridge: Cambridge University Press, 1975); Stefan Hohmann, Friedenskonzepte: Die Thematik des Friedens in der deutschsprachigen politischen Lyrik des Mittelalters. Ordo, 3 (Cologne, Weimar, and Vienna: Böhlau 1992); Albrecht Hagenlocher, Der guote vride: Idealer Friede in deutscher Literatur bis ins frühe 14. Jahrhundert. Historische Wortforschung, 2 (Berlin and New York: Walter de Gruyter 1992); Ines-Jacqueline Werkner, Gerechter Frieden: Das fortwährende Dilemma militärischer Gewalt. Perspektiven. Essays aus der FEST, 1 (Bielefeld: transcript-Verlag, 2018); see now Larry May, The Cambridge Handbook of the Just War. Cambridge Handbooks in Philosophy (Cambridge: Cambridge University Press, 2018).

12. Wolfgang F. Stammler et al. (Eds.), Erasmus of Rotterdam, Über Krieg und Frieden (On War and Peace.) Bibliothek historischer Denkwürdigkeiten (Essen: Alcorde Verlag, 2018), 177-240.

13. Eckart Conrad Lutz, Spiritualis fornicatio: Heinrich Wittenwiler, seine Welt und sein 'Ring'. Konstanzer Geschichts- und Rechtsquellen, 32 (Sigmaringen: J. Thorbecke Verlag, 1990); Albrecht Classen, "Heinrich Wittenwiler," German Writers of the Renaissance and Reformation 1280-1580, Dictionary of Literary Biographies, 179, ed. James Hardin and Max Reinhart (Detroit, Washington, DC, and London: Gale Research, 1997), 326-331. 
dancing partner, Gretel, by scratching her palm too hard, making it bleed (644965. ${ }^{14}$ This occurs during the wedding festivities and is entirely unrelated to Bertschi's or Metzli's performance at that moment. Eisenbeißer certainly acts impetuously and treats the poor woman a little too rough, but he had no intention of hurting her, although her uncle immediately intervenes and severely blames his opponent for his bad behavior. The latter is not a man to accept such criticism lightly, retorts with foul words, threatening to rape both the other's mother and niece, from which quickly erupts an aggressive exchange of words between the two men, and this then turns first into a big brawl, whereupon all the guests have to flee, then subsequently into a veritable war.

Wittenwiler views and describes the peasants in most sarcastic terms and ridicules them in every possible way. ${ }^{15}$ Whatever situation they are in, they behave foolishly, crudely, and ultimately violently. The allegory sets in with a violent game of jousting against the knight Neidhart, who is by far superior to them all and injures badly every opponent. They do not understand the deception and why and how they are victimized, but all this sets the tone for the subsequent development that ultimately leads to the conflict at the wedding. While the peasants from Lappenhausen at first can use their home advantage and chase those from Nissingen away, the latter soon prepare themselves effectively for a real war, in which, tragically, they defeat their opponents and basically wipe out the entire village. Even Mätzli is killed, whereas only Bertschi survives, whom the enemies cannot reach because he has found refuge in the attic of a barn. They besiege him, but when he then pretends to have lost his mind, eating hey, they get scared and depart. But the outcome of the entire war proves to be so devastating for the foolish protagonist, and he is so shocked to see everyone dead, including his bride, that he travels to the Black Forest and settles there as a hermit without having ever understood what the cause for the catastrophe might have been. He is, like everyone else in Lappenhausen, an utter fool and not competent

14. Heinrich Wittenwiler, Der Ring: Text - Übersetzung - Kommentar, ed. Werner Röcke (Berlin and Boston: Walter de Gruyter, 2012). All translations into English are my own. As much as Wittenwiler's text has attracted considerable scholarly attention (see the bibliography on pp. 505-516, there are not many monographic studies on this allegory; but see Corinna Laude, "Daz in swindelt in den sinnen ...": Die Poetik der Perspektive bei Heinrich Wittenwiler und Giovanni Boccaccio. Philologische Studien und Quellen, 173 (Berlin: Erich Schmidt, 2002). See also Albrecht Classen, "Rape in the World of the Peasant Class in the Late Middle Ages: Heinrich Wittenwiler's Ring," id., Sexual Violence and Rape in the Middle Ages: A Critical Discourse in Premodern German and European Literature. Fundamentals of Medieval and Early Modern Culture, 7 (Berlin and Boston: Walter de Gruyter, 2011), 143159.

15. Alan Baragona and Elizabeth L. Rambo (Eds.), Words that Tear the Flesh: Essays on Sarcasm in Medieval and Early Modern Literature and Cultures. Fundamentals of Medieval and Early Modern Culture, 21 (Berlin and Boston: Walter de Gruyter, 2018); unfortunately, the sarcasm in Wittenwiler's text is not addressed here. 
enough to comprehend his own life and the external circumstances. Bertschi realizes that he had received many valuable lessons from his advisors and teachers, but he had never fully paid attention to the instructions and so failed completely in all of his endeavors: "Das ich so weysleich was gelert / Vnd mich so wenig dar an chert" (9680-81; Horrible to realize that I was so wisely schooled and cared so little about it). The results, however, are that everyone in his family, in his social community, and even his bride is dead. For him, all this only means that everything in this world is transitory, except for God's eternal love (9690).

According to Wittenwiler, the miserable protagonist gained the salvation of his soul after he had retired from the world (9696), but at the huge price of losing everyone in his village to the slaughter by the enemies. Sadly, Bertschi is not the kind of person to understand the causes and consequences of his actions, and the same applies to the other inhabitants of his village of Lappenhausen. Those all die, Bertschi survives, but those peasant figures prove to be nothing but victims; they never gain intellectual agency and are helpless in the face of the military development.

Of course, Wittenwiler accuses the peasants of being completely foolish, crude, violent, rash, ignorant, and aggressive, not able to pursue any rational concepts and being victims of their illusions. But it is very clear that the peasants stand in for the average person normally lacking a certain degree of intelligence. The poet is careful to exclude urban burghers, whereas knights and other characters also appear getting involved in the devastating war and are hence also engulfed by it. Despite many theoretical lessons about marriage, proper behavior in public, and war, none of the teachings help to overcome violence. From early on, the peasants want to enjoy the reputation of knights but remain pathetic victims of the mean-spirited and deceptive treatment by the outsider, the knight Neidhart. However, the latter also betrays his own ideals and brutally plays with his opponents, many of whom die in their attempt to imitate knightly life.

Most fatally, the social interactions during the wedding festivities near the end of the allegory underscore most dramatically that the peasants, who are supposed to represent people at large, fail in every respect to operate rationally and reasonable, and who thus become victims of their own violence and foolishness. Not surprisingly, the representatives of the cities decide, after long and wise deliberations, to stay away from this military conflict since they do not want to side with either village, unless reasonable conditions would require their assistance, as especially the councilor from Constance-maybe the poet's indirect self-reference-elaborates in his highly praised speech (7772-846).

Following his recommendations that bystanders such as the cities should not intervene with military means and should try, instead, to advise and help constructively by dint of wise counsel (7824), they smartly decide to stay out of this rash conflict because they would otherwise become victims of the war which in fact engulfs, at the end, all men, women, children in the village of 
Lappenhausen, and then even the farms and all goods (9661-66), apart from the miserable Bertschi. ${ }^{16}$

However, as much as Wittenwiler's Ring appears to be a ghastly satire on the world of peasants, ${ }^{17}$ we have also to realize that in its allegorical dimension this romance turns into a severe criticism of violence and military aggression resulting from ignorance and lack of self-control at large. The poet identifies most specifically that even a smallest incident such as the unintentional scratching of a hand leading to some bleeding can trigger war because foolish people easily get into conflicts with each other. While the audience was certainly invited to laugh about Bertschi and his fiancée Mätzli, along with their relatives and friends, the outcome of this massive narrative amounts to a tragedy mirroring the devastating consequences of war globally.

Although there are enough teachings provided throughout the text which all sound reasonable and reflect commonsense, no one in this work knows how to observe the principles of communication since everyone allows their own emotions and vices to rule their lives, apart from the representatives of the cities. ${ }^{18}$ Thus, war erupts and devours everyone in the village of Lappenhausen, which made Wittenwiler's narrative to a most powerful allegorical warning which, however, obviously did not appeal to the contemporaries since the text has survived in one manuscript only. ${ }^{19}$ Poets speaking up against the war, especially in the pre-modern world, obviously met with little love for their criticism, and this at a time when the ideals of knighthood and the ever-stronger efforts to develop new weapons clashed with each other. Moreover, late medieval Europe faced the global threat by the Ottomans, and internecine strife was almost routine everywhere. Naturally, a major satirical text such as Der Ring did not appeal to a rather militaristic society, especially because it was composed only at the dawn of the anti-war discourse.

16. Pamela Kalning, Kriegslehren in deutschsprachigen Texten um 1400: Seffner, Rothe, Wittenswiler; mit einem Abdruck der Wiener Handschrift von Seffners "Ler von dem streitten". Studien und Texte zum Mittelalter und zur frühen Neuzeit, 9 (Münster, New York, et al.: Waxmann, 2006).

17. Ulrich Gaier, Satire: Studien zu Neidhart, Wittenwiler, Brant und zur satirischen Schreibart (Tübingen: Max Niemeyer, 1967).

18. This issue is examined at greater length already in Albrecht Classen, Verzweiflung und Hoffnung. Die Suche nach der kommunikativen Gemeinschaft in der deutschen Literatur des Mittelalters. Beihefte zur Mediaevistik, 1 (Frankfurt a. M., Berlin, et al.: Peter Lang, 2002), 401-435.

18. http://www.handschriftencensus.de/werke/1897. [Accessed 21 October 2018] See also Werner Röcke (Ed.) (see note 13), X.

19. See also Werner Röcke (Ed.) (see note 13), X. 


\section{Hans Jacob Christoffel von Grimmelshausen}

The situation radically changed, however, already in the seventeenth century when Hans Jacob Christoffel von Grimmelshausen (1621/22-1676) published, in the wake of the Thirty Years' War with its devastating consequences for a wide swath of the German population, his Abentheuerliche Simplicissimus Teutsch in 1669..$^{20}$ Much is known about the author and his success as a writer, but for our purposes we only need to remember that he was kidnapped by Hessian soldiers in 1635 and from that time on personally witnessed many of the horrors of the war, sometimes serving in the Swedish army, sometimes in the imperial army until 1649. From that time until 1661 he worked as a castellan (castle administrator) for the counts of Schauenburg.

In 1662 he transitioned to a parallel post for the Straßburg physician Johannes Küfer the Younger and served in that administrative role until 1665. After a year as an inn-keeper, the Straßburg archbishop Franz Egon von Fürstenberg appointed him as a magistrate of the little town of Renchen in Baden in south-west Germany in 1667. In 1673, the French King Louis XIV embarked on a war against the Habsburg emperor Leopold I, which forced Grimmelshausen to enter the military service once again, this time under his lord, the archbishop, who sided with King Louis XIV. Nevertheless, in his rank as city magistrate he could dedicate much of his time to literary interests, and he thus emerged quickly as one of the most important German Baroque poets of his time. His Simplicissimus was certainly influenced by the Spanish picareque novel, and yet also included many autobiographical features. ${ }^{21}$

It cannot be the purpose here to take the entire novel into view and to problematize its literary treatment of the Thirty Years' War once again. As in the case of Wittenwiler's Ring, I can only turn my attention to the critical reflections on the war and the comments on the brutal actions by the mercenaries in their deadly misuse of the peasant population as we discover it in the early section of the novel. Here we encounter the protagonist as a child, Simplicissimus (Lat.: The Most Simple Minded One), who observes many horrors but does not fully understand their meaning.

In the later development, conditions become much worse for him, or much better, depending on the circumstances, each time shedding startling light on the

20. Hans Jacob Christoffel von Grimmelshausen, Werke, ed. Dieter Breuer, volume I.1. Bibliothek der Frühen Neuzeit, 4.1 (Frankfurt a. M.: Deutscher Klassiker Verlag, 1989).

21. See, for example, Dieter Breuer, Grimmelshausen-Handbuch (Munich: Fink, 1999); Volker Meid, Grimmelshausen: Leben, Werk, Wirkung (Stuttgart: Philipp Reclam jun., 2011); Heiner Boehncke and Hans Sarkowicz, Grimmelshausen: Leben und Schreiben: vom Musketier zum Weltautor (Berlin: AB - Die Andere Bibliothek, 2018); for a detailed and welldocumented online biography, see https://de.wikipedia.org/wiki/Hans_Jakob_Christoffel _von_Grimmelshausen [Accessed 30 March 2021] 
brutality and vagaries of the war (e.g., chs xxvii-xxviii, 213-20). However, the naiveté with which the young boy describes the horrible destiny of his family which is attacked and killed by a marauding troop of lansquenets, illustrates perhaps most impressively the actual suffering people had to go through. War is here described through the eyes of a child who does not quite understand, and yet conveys in truly chilling terms how the murderous soldiers rape, torture, and kill the people. Of course, we clearly recognize here the author himself who wrote this novel in his old age, drawing many registers in composing and structuring his text, deliberately projecting the violence in this early scene as something incomprehensible and outlandish, as children indeed would perceive it, not knowing anything about good and evil, being completely innocent and naive (20). Although rape, torture, burning, strangling, and other forms of killing take place, Simplicissimus does not understand the meaning of it all and actually laughs about some of the scenes taking place in front of his eyes.

At first, the young narrator outlines the quasi paradisiacal conditions of his family farm in the Spessart forest (today near Aschaffenburg, east of Frankfurt a. M.). Despite the seemingly playful tone of his voice, we are explicitly told that the soldiers committed horrible cruelties (27), which were representative of all the terrible things that happened in this long war devastating many parts of Germany. As much as the narrator describes himself when he was a child as completely naive and ignorant about the conditions of the world, he powerfully projects a horrifying scene when the soldiers arrive and attack the entire farm and the family.

After they had tied up their horses, they began to kill many of the farm animals and prepared them as food. Others rage through the house in search of money; even the toilet is examined closely (28). All the clothes and household items are piled together and taken away. Everything else is destroyed, with the lansquenets not demonstrating any mercy or any human instincts. The bed comforters are emptied out, and filled with bacon and other dried meat to be transported away. Others again willfully destroy the oven and break the windows, which the childish narrator comments, "als haetten sie ein ewigen Sommer zu verkuendigen" (28; as if they had to announce the arrival of eternal summer). Although there is plenty of fire wood in the yard, they break apart all furniture and burn them.

The farm maid is gang-raped so badly that she cannot even leave the barn anymore, probably dying from her heavy injuries and blood loss, while the farmhand is tortured through the use of waterboarding, although the lansquenets force sewer instead of water into his mouth, and this with the help of a funnel, which they call the 'Swedish drink.' This horrible treatment makes him break down quickly, so he takes them to the place where other people and their animals are hiding, that is, especially the protagonist's parents and another woman. Now the soldiers use thumb screws to torture the helpless victims; one of the peasants they burn alive in the oven, while another is brutally strangled so badly that 
blood spurts out of his mouth, nose, and ears. Sarcastically, the narrator emphasizes that each one of the soldiers had his own "inventio" (29) to cause pain and endless suffering.

Foolishly laughing with and about his own father, the young boy comments with astonishment how the soldiers tortured his own father, his Knan. Whereas all the others experienced horrendous pain or were killed, the Knan is tied up tightly, his naked feet are rubbed in wet salt, which then the old goat is licking off. Simplicissimus finds this scene so hilarious that he joins in the laughter: "das kam so artlich / daß ich Gesellschaft halber/oder weil ichs nicht besser verstunde/von Hertzen mit lachen musste" (29; this was so entertaining that I had to burst out laughing myself, either because my father's laughter was so infectious, or because I did not understand it better).

As to the women, old and young, Simplicissimus does not know what happened to them because the soldiers did not allow him to witness what happened. He can only report that he heard the women scream for pain, all of them obviously being raped, including his own mother and the maid Ursula. During all that horror, the young boy assiduously assists the lansquenets in the preparation of food, watering the horses, and the like, not grasping in the slightest who they are, what they do, and in what danger he finds himself in. But when he finally happens to enter the shed where the badly wounded maid is about to expire in her terrible suffering, she tells him with her weak voice to run away and so to save his life (30). This Simplicissimus manages to do in the evening, but he only encounters endless new problems, not knowing anything about the forest, being completely alone, and simply lost, after his entire family has been tortured and killed, and the farm burned down to the ground. The lonely child returns there the next morning, finding no one alive there (30), when he is suddenly confronted by five horsemen, obviously from northern Germany, as their dialect indicates. He is so scared that he cannot move or respond to the soldiers, one of whom gets so irritated because they cannot reach the boy due to a swamp separating them that he pulls his gun and shoots at him. Although he misses the child, Simplicissimus collapses out of fear and does not move until the arrival of the night, when he leaves the family ground and enters the forest, that is, when his new life begins, although he still represents a total simpleton and knows nothing about God and the world, as a hermit quickly realizes whom he encounters soon after (ch. VIII, 37-39).

Grimmelshausen certainly modeled this text on the basis of many other novels and romances dealing with a foolish child who first needs to grow up and learn the basics of this world, such as Wolfram von Eschenbach's Parzival (ca. 1205). When Wilhelm Dilthey coined the term "Bildungsroman" for this genre in 1870, he had in mind mostly novels from the eighteenth and nineteenth centuries, but both Simplicissimus and Parzival were already predicated on this narrative 
pattern and can be safely identified as important precursors to this genre.22 The protagonist subsequently is exposed to many different war settings and experiences many ups and downs in his life, all determined by the vagaries of the war.

After the death of the hermit, for instance, who had taken care of him for a while, the hero tries to secure advice from the priest in a nearby village, but has to witness another terrible raid by mercenaries, who are about to kill everyone, including the priest, when a group of peasants come rushing up and chase them away, which the narrator again sarcastically calls "Kurtzweil" (53; entertainment), but now with the proviso that these events would have almost robbed him of any interest in exploring the outside world, which he regards as most dangerous. The novel would have come to a quick closure at that point if Simplicissimus would have been able to realize his initial decision, but neither violence nor the war at large spare him, and expel him from his sylvan solitude out into the world, where he has to endeavor somehow to survive.

Grimmelshausen does not spare us even the most cruel and horrifying experiences, of peasants torturing and killing mercenaries, and the latter doing the same to the former, depending on who is fortunate enough in their fighting. The entire world of the Thirty Years' War comes to 'life' in this terrifying novel, and there is no doubt about the author's strong effort to condemn the dehumanization and bestiality committed many times. Simplicissimus survives, surprisingly, and becomes the witness of the countless crimes and killing throughout the decades-long war, and thus the author conveys most drastic literary images of the cruelty of war on the audience, which might well have been the most daunting ever created in the literary history in Europe from the early Middle Ages until the late seventeenth century. The protagonist at the end abandons his home country and departs for the Orient, though he experiences a shipwreck near Madagascar in the Indian Ocean and survives on a mysterious island, never to be heard from again.

Little wonder that this major Baroque novel, which was well received and translated into various languages, ${ }^{23}$ concludes with the protagonist's words of

22. For a list of typical representatives of this genre, including both works cited here, see the useful list compiled at: https://en.wikipedia.org/wiki/Bildungsroman\# Precursors (last accessed on March 30, 2021), with an extensive bibliography, which pertains, however, exclusively to the modern literary history. Cf. Ortrud Gutjahr, Einführung in den Bildungsroman. Einführungen Germanistik (Darmstadt: Wissenschaftliche Buchgesellschaft, 2007); see also Petru Golban, A History of the Bildungsroman: From Ancient Beginnings to Romanticism (Newcastle upon Tyne: Cambridge Scholars Publishing, 2018); Elisabeth Böhm and Katrin Dennerlein (Eds.), Der Bildungsroman im literarischen Feld: neue Perspektiven auf eine Gattung. Studien und Texte zur Sozialgeschichte der Literatur, 144 (Berlin and Boston: Walter de Gruyter, 2018).

23. Italo Michele Battafarano, Simpliciana Bellica: Grimmelshausens Kriegsdarstellung und ihre Rezeption 1667-2006. Iris, 26 (Bern, Frankfurt a. M., et al.: Peter Lang, 2011). 
good-bye to this world because it cannot be trusted and tends to deceive all people, who live only a short time and then have to face death (ch. XXIV, 544551. $)^{24}$ Here Grimmelshausen again draws on a long literary tradition, intermingled with deep theological roots, but his novel proved to be a masterpiece of a unique kind because of the most somber descriptions of war and its aftermath. He introduces us both to actual war scenes, and also, perhaps most importantly, to the brutality and cruelty of the individual troops of lansquenets against the civil population.

\section{Erich Maria Remarque's Im Westen nichts Neues}

The next stage in this discourse on war was reached in the early twentieth century when Erich Maria Remarque (1898-1970) published his world-famous novel Im Westen nichts Neues, or All Quiet on the Western Front, in 1929. Although this work quickly turned into a bestseller, with 2.5 million copies sold in 22 languages in its first 18 months in print, and although it quickly aroused the ire of the Nazis who had it banned and burned next to many other books after they had risen to power in 1933, it has continued to be one of the most successful titles in the history of German literature, today available in more than 50 languages, having been sold in over 60 million copies. ${ }^{25}$

In many respects, this novel represents the prime example of anti-war literature, describing the life of the deeply traumatized protagonist, Paul Bäumer fighting on the western front in the First World War. We follow him through the military training and on his way to the front, where he experiences all the horror of modern warfare, although he manages for a long time to survive, until death also hits him, curiously at a rather calm day, when he becomes a victim of hostile artillery, and this just shortly before the end of the war - hence the sarcastic title of the novel. Even though Bäumer is allowed from time to time to go home on short visits of his family, the war has shaped him so deeply that the communication with the civilians proves to be virtually impossible. Remarque highlights the impact of the modern weapons technology, the use of toxic gas, the machine gun, and especially the horrors of the direct exchanges with the enemy, ultimately even the immediate killing of each other when hiding in trenches or in a bomb crater. At the end, all meaning of war has been lost, and the protagonist

24. Jana Maroszová, Denn die Zeit ist nahe: Eschatologie in Grimmelshausens Simplicianischen Schriften: Zeit und Figuren der Offenbarung. Beihefte zu Simpliciana, 8 (Bern: Peter Lang, 2013).

25. https://www.die-besten-aller-zeiten.de/buecher/meistverkauften/. [Accessed 30 March 2021]; the figure listed here, 20 million, can probably be upped to 40 million considering the countless pirated editions. Erich Maria Remarque, Im Westen nichts Neues (Berlin: Propyläen Verlag, 1929). 
no longer understands what purpose there might be behind their mutual killing. Little wonder that the Nazis strongly rejected Remarque's novel which they regarded as defeatist and anti-patriotic, and also no surprise that it nevertheless resonated so strongly across the world until today because it exposes powerfully the absurdity and meaninglessness of all wars in which the soldiers become nothing but cannon fodder.

Remarque published many other novels, wrote screenplays, movie scripts, he lived in Switzerland, in the US, and then moved back to Switzerland, and he had many different relationships with various women, even with Marlene Dietrich. When he died in 1970,26 the author still believed that most people would be pacifists, but it also dawned upon him, as we know it today only to clearly, that the civilians who profit from the war under any circumstances really support and promote military conflicts because those create money for them.

Scholars have spent much attention on this novel, and it would be difficult to achieve a new reading of Remarque's message, except for integrating his novel into the long-term anti-war discourse, as it had set in with Wittenwiler's allegory already in the fifteenth century. The latter had still enjoyed the liberty of depicting a war affecting 'only' a village populated by foolish peasants, whereas the outside world smartly stayed out of the conflict. Grimmelshausen presented a world in which the war had devastating consequences especially for the civilian population, but the protagonist could survive, despite many dangers and severe conflicts. Remarque, by contrast, dealt with the worst war the world had ever seen up to that time, so he depicted the military situation in most gruesome terms, not leaving hope for the audience that any good could come out of that situation. ${ }^{27}$

We could choose many scenes in this momentous novel, which naturally deeply angered, to emphasize this point once again, the Nazis because it aggressively undermined all traditional militaristic ideologies and any attempt at glorifying war as the ultimate catalyst for the strong man to prove himself to the world, as Ernst Jünger was to do in his rather callous, nationalistic, or later mostly deterministic novel In Stahlgewittern (1920, revised eleven times, and reissued in

26. Alfred Antkowiak, Erich Maria Remarque: Leben und Werk, $2^{\text {nd }}$ revised edition. Schriftsteller der Gegenwart, 14 (Berlin: Volk und Wissen, 1977); Erich Maria Remarque: Leben, Werk und weltweite Wirkung, ed. Thomas F. Schneider. Erich-Maria-RemarqueJahrbuch, 8 (Osnabrück: Rasch, 1998); see also the other volumes in the same series; cf. Thomas Schneider, Unabhängigkeit, Toleranz, Humor: Independence, Tolerance, Humor: Erich Maria Remarque 1898-1970 (Osnabrück: Universitäts-Verlag Rasch, 2001).

27. Elisabeth Krimmer, The Representation of War in German Literature: From 1800 to the Present (New York: Cambridge University Press, 2010); Noah Berlatsky, War in Erich Maria Remarque's All Quiet on the Western Front (Farmington Hills, MI: Greenhaven Press, 2013); Murdoch, Brian (Ed.), German Literature and the First World War: The Anti-War Tradition: Collected Essays. Ashgate Studies in First World War History (Farnham, Surrey: Ashgate Publishing Limited; Burlington, VT: Ashgate Publishing Company, 2015). 
1922, 1924, 1934, 1935, 1940, 1961, 1978, 1985, 2013, 2015, etc.) ${ }^{28}$ For our purposes, one brief description of a sudden change in the development of the trench war must suffice to illustrate the (de)aestheticizing strategies by this author in his efforts to come to terms with war.

At a seeming lull in the constant barrage by artillery fire, the protagonist and his fellow soldiers jump out of their hiding because the enemy is suddenly making an attack. The narrator expresses his amazement that "in dieser zerwühlten Wüste noch Menschen sein können" (115; people still could exist in this torn-up desert). The narrator does not share his emotions and limits his report to a factual account of the mechanical sounds by the machine guns and rifles. Two of Paul's comrades throw hand grenades as fast as possible, and yet the French soldiers are approaching them, and this despite "sichtbare Verluste" (115; visible losses). But people are here no longer people; they are objects which machine gun fire decimates in whole rows.

Then, however, Paul has a strange personal encounter with one of the enemies, a young man who falls into a barbed-wire barrier, when the machine gun shoots off his hands. Those remain hanging in the wire, "als wollte er beten" (116; as if he wanted to pray). In the next moment, Paul faces another soldier who fixates him with his eyes, which makes it impossible for him to throw a grenade and thus to kill the man. Nevertheless, in the next second, he notices that the opponent is lifting his hand, moves it suspiciously, obviously preparing to shoot, so Paul throws the grenade, after all, and kills him. Soon the entire company has to withdraw, and he realizes: "Aus uns sind gefährliche Tiere geworden. Wir kämpfen nicht, wir verteidigen uns vor der Vernichtung" (16; We have turned into dangerous animals. We do not fight, we defend ourselves against the destruction). While before the soldiers had been helplessly exposed to endless artillery fire, and this for three days, the attack by the French made it possible for them to release all their fury, frustration, anxiety, and rage, and then simply kill, "um uns zu retten und zu rächen" (117; in order to save ourselves and to get revenge).

The barbarity of this war can no longer be superseded, especially because the mechanization of the killing and the desperation in face of dead soldiers everywhere assumes unforeseen dimensions. There is no humanity left in them, they are only bent on fighting, killing, and trying to survive: "Käme dein Vater mit denen drüben, du würdest nicht zaudern, ihm die Granate gegen die Brust zu werfen" (117; If your father came with those on the other side, you would not hesitate to throw the grenade at his chest). And when the own forces succeed to throw back the enemies, there are no comments on the human aspect: "Der Angriff wird zerfetzt durch unsere Artillerie" (118; the attack is shredded into pieces by our artillery). The absurdity of war is thus profiled in shocking terms,

28. Schöning Matthias (Ed.), Ernst Jünger-Handbuch: Leben - Werk - Wirkung (Stuttgart and Weimar: Verlag J. B. Metzler, 2014). 
and Remarque did not even have the strength to argue in any meaningful or effective ways for pacifism, for ending the war, for peace, for humanity. The age of the military machine had begun; there was no real hope left.

\section{Conclusions}

Curiously, as popular as Remarque's novel proved to be, pro-war literature such as by Jünger also achieved enormous successes parallel to his. In fact, and quite tragically, not one of these literary works that opposed war had any significant impact on the further development of war technology, military aggression, or warfare itself. Nevertheless, all three writers discussed here offered their audiences profound literary expressions of what the true consequences of war were like and ripped off the mask of the glorified war, presenting the true consequences and the horror behind the military ideology. We might never be able to identify specifically how much impact the literary discourse might actually have on the social, economic, and political conditions. In fact, as we probably would have to admit, the threat of war against all mankind has become ever worse since the late Middle Ages, and today we face the possible annihilation of mankind through a potential nuclear war.

Would we thus have to conclude that those three writers failed to achieve their goals? Is the literary expression truly completely helpless to speak up against the proliferation of weapons and military violence? Did not philosophers such as Erasmus of Rotterdam or Immanuel Kant argue cogently and influentially against waging wars, and yet then had to realize that the authorities did not even care about their ideas? We could also cite a long list of powerful theologians from Augustine to Karl Barth, for instance, who bolstered the discourse on just war and peace and yet had to realize that those in power did not listen to them.

Nevertheless, Wittenwiler, Grimmelshausen, and Remarque still achieved a monumental task, just as the other intellectuals mentioned above. They gave highly meaningful expression to the horrors of war and painted deeply impactful images of the mass murder, destruction, and global devastation of military violence. As much as their narratives contributed to the literary treatment of war, as much they also empowered their readers to reflect profoundly on the consequences of war. The anti-war movement, which might have started with Wittenwiler, so to speak, might not have been able to realize its goal, peace, which could easily be just an illusion considering human nature, but this movement is not going away and will continue to combat the warmongers and expose their true motives, to gain more money and power at the cost of infinite human suffering. In each text discussed above, the outcome of the war is pure devastation, horror, and global loss, not only of lives and goods, but of the human 
spirit, human ethics, and human values, as Andreas Gryphius formulated so insightfully in his sonnet, "Tränen des Vaterlands" (1637; Tears of the Fatherland.) ${ }^{29}$

In the case of Wittenwiler's Ring, the war destroys one village community; in the case of Grimmelshausen, the war severely endangers the civilian population; in the case of Remarque the war dehumanizes every war participant and threatens the entire European continent and culture. The war machine is taking over and rules totally, decimating the human spirit, as Paul Bäumler ruminates at the end: "Wenn wir jetzt zurückkehren, sind wir müde, zerfallen, ausgebrannt, wurzellos und ohne Hoffnung" (286; When we return home now, we are tired, have fallen apart, are burnt out, without roots and hope). Wittenwiler still projected a world where the intelligent representatives of the cities refuse to get involved in a war which they can only identify as foolish. Grimmelshausen already had to depict the fighting marauders and lansquenets as beast-like, inhuman, and Remarque recognized that technology suddenly ruled, also in the war, victimizing the human being entirely. The anti-war discourse continues until today, but wars all over the world do so as well.

The question remains for us to answer, as scholars and as individuals, why are there wars, who are we as human beings to allow such globally destructive forces to exert themselves, and what can the literary discourse contribute to combat against universal military aggression? As hopeless as it all might sound, we should not give up and should remember that the human struggle for a better society continues. Even if the literary voices are so ineffective in bringing about concrete changes in reality, they constitute a discourse of great significance which we all can and must listen to. Our critical engagement with these works constitutes one important strategy to instill anti-war sentiments in the younger generation, asking them to listen to so many different voices addressing the same concerns, and this already since the early fifteenth century.

\section{Bibliography}

Althoff, Gerd. Frieden stiften: Vermittlung und Konfliktlösung vom Mittelalter bis heute (To Establish Peace: Negotiations and Solving of Conflicts from the Middle Ages to Today). Darmstadt: Wissenschaftliche Buchgesellschaft, 2015.

Antkowiak, Alfred. Erich Maria Remarque: Leben und Werk (Erich Maria Remarque: Life and Work). $2^{\text {nd }}$ Revised Edition. Schriftsteller der Gegenwart, 14. Berlin: Volk und Wissen, 1977.

Ashe, Laura and Ian Patterson (Eds.) War and Literature. Essays and Studies, 67. Cambridge: D. S. Brewer, 2014.

29. Albrecht Classen, "Boethius and No End in Sight: The Impact of De consolatione philosophiae on Early Modern German Literature from the Fifteenth through the Seventeenth Century: Andreas Gryphius and Johann Scheffler (Angelus Silesius,)" Daphnis 46 (2018): 448-466. 
Auerbach, Erich. Kultur als Politik: Aufsätze aus dem Exil zur Geschichte und Zukunft Europas (1938-1947) (Culture as Politics: Essays from the Exile on the Past and Future of Europe (1938-1947). Edited by Christian Rivoletti. Constance: Konstanz University Press, 2014.

Baragona, Alan, and Elizabeth L. Rambo (Eds.) Words that Tear the Flesh: Essays on Sarcasm in Medieval and Early Modern Literature and Cultures. Fundamentals of Medieval and Early Modern Culture, 21. Berlin and Boston: Walter de Gruyter, 2018.

Battafarano, Italo Michele. Simpliciana Bellica: Grimmelshausens Kriegsdarstellung und ihre Rezeption 1667-2006 (Simplicana Bellica: Grimmelhausen's Presentation of War and Ist Reception 1667-2006). Iris, 26. Bern, Frankfurt a. M., et al.: Peter Lang, 2011.

Baty-Delalande, Hélène and Maxime Decout (Eds.) Écrits de guerre: laboratoires esthétiques (Writings about War: Esthetic Laboratories). Revue de Sciences Humaines, 326. Villeneuve d'Ascq: Septentrion, 2017.

Berlatsky, Noah. War in Erich Maria Remarque's All Quiet on the Western Front. Farmington Hills, MI: Greenhaven Press, 2013.

Boehncke, Heiner and Hans Sarkowicz. Grimmelshausen: Leben und Schreiben: vom Musketier zum Weltautor (Grimmelshausen: Life and Writing: From Being a Musqueteer to a World Author). Berlin: AB - Die Andere Bibliothek, 2018.

Böhm, Elisabeth and Katrin Dennerlein (Eds.) Der Bildungsroman im literarischen Feld: neue Perspektiven auf eine Gattung (The Bildungsroman in the Literary Field: New Perspectives on a Genre). Studien und Texte zur Sozialgeschichte der Literatur, 144. Berlin and Boston: Walter de Gruyter, 2018.

Breuer, Dieter. Grimmelshausen-Handbuch (Grimmelshausen Handbook). Munich: Fink, 1999.

Brunner, Horst (Ed.) Der Krieg im Mittelalter und in der Frühen Neuzeit: Gründe, Begründungen, Bilder, Bräuche, Recht (War in the Middle Ages and the Early Modern Period: Causes, Explanations, Images, Customs, Law). Imagines medii aevi, 3. Wiesbaden: Reichert, 1999.

Brunner, Horst (Ed.) Die Wahrnehmung und Darstellung von Kriegen im Mittelalter und in der Frühen Neuzeit (The Perception and Presentation of War in the Middle Ages and the Early Modern Period). Imagines medii aevi, 6. Wiesbaden: Reichert Verlag, 2000.

Calloway, Catherine. "War in Literature and Drama." Oxford Bibliographies Jan. 11, (2018). Retrieved from: https://bit.ly/3wWfU3d. [Accessed 30 March 2021]

Classen, Albrecht. "Heinrich Wittenwiler," German Writers of the Renaissance and Reformation 1280-1580. Dictionary of Literary Biographies, 179, edited by James Hardin and Max Reinhart. Detroit, Washington, DC, and London: Gale Research, 1997, 326-331.

Classen, Albrecht. Verzweiflung und Hoffnung. Die Suche nach der kommunikativen Gemeinschaft in der deutschen Literatur des Mittelalters (Despair and Hope: The Quest for the Communicative Community in Medieval German Literature). Beihefte zur Mediaevistik, 1. Frankfurt a. M., Berlin, et al.: Peter Lang, 2002.

Classen, Albrecht. "Rape in the World of the Peasant Class in the Late Middle Ages: Heinrich Wittenwiler's Ring." In Sexual Violence and Rape in the Middle Ages: A Critical Discourse in Premodern German and European Literature. Fundamentals of Medieval and Early Modern Culture, 7. Berlin and Boston: Walter de Gruyter, 2011, 143-159.

Classen, Albrecht and Nadia Margolis (Eds.) War and Peace: Critical Issues in European Societies and Literature 800-1800. Fundamentals of Medieval and Early Modern Culture, 8. Berlin and New York: Walter de Gruyter, 2011. 
Classen, Albrecht. "Boethius and No End in Sight: The Impact of De consolatione philosophiae on Early Modern German Literature from the Fifteenth through the Seventeenth Century: Andreas Gryphius and Johann Scheffler (Angelus Silesius)." Daphnis 46 (2018): 448-466.

Dawes, James. The Language of War: Literature and Culture in the U.S. from the Civil War through World War II. Cambridge, MA, and London: Harvard University Press, 2002.

Gaier, Ulrich. Satire: Studien zu Neidhart, Wittenwiler, Brant und zur satirischen Schreibart (Satire: Studies on Neidhart, Wittenwiler, Brant, and on the Satirical Writing Style). Tübingen: Max Niemeyer, 1967.

Golban, Petru. A History of the Bildungsroman: From Ancient Beginnings to Romanticism. Newcastle upon Tyne: Cambridge Scholars Publishing, 2018.

Grimmelshausen, Hans Jacob Christoffel von. Werke (Works). Edited by Dieter Breuer. Volume I.1. Bibliothek der Frühen Neuzeit, 4.1. Frankfurt a. M.: Deutscher Klassiker Verlag, 1989.

Gutjahr, Ortrud. Einführung in den Bildungsroman (Introduction to the Bildungsroman). Einführungen Germanistik. Darmstadt: Wissenschaftliche Buchgesellschaft, 2007.

Hagenlocher, Albrecht. Der guote vride: Idealer Friede in deutscher Literatur bis ins frühe 14. Jahrhundert (The Good Peace: Ideal Peace in German Literature up to the Early $14^{\text {th }}$ Century). Historische Wortforschung, 2. Berlin and New York: Walter de Gruyter 1992.

Harvey, A[rnold]. D. A Muse of Fire: Literature, Art and War. London and Rio Grande, $\mathrm{OH}$ : Hambledon Press, 1998.

Hohmann, Stefan. Friedenskonzepte: Die Thematik des Friedens in der deutschsprachigen politischen Lyrik des Mittelalters (Concepts of Peace: The Theme of Peace in German Political Lyric Poetry from the Middle Ages). Ordo, 3. Cologne, Weimar, and Vienna: Böhlau 1992.

Homann, Ursula. Der Krieg in der Literatur (War in Literature.) Retrieved from: http:// www.ursulahomann.de/DerKriegInDerLiteratur/kap001.html. [Accessed 30 March 2021]

Houen, Alex and Jan-Melissa Schramm (Eds.) Sacrifice and Modern War Literature: From the Battle of Waterloo to the War on Terror. Oxford: Oxford University Press, 2018.

Hunt, Irmgard Elsner. Krieg und Frieden in der deutschen Literatur; vom Barock bis heute (War and Peace in the German Literature: From the Baroque to Today). Europäische Hochschulschriften. Reihe 1: Deutsche Sprache und Literatur, 798. Frankfurt a. M., Bern, and New York: Peter Lang 1985.

Hyne, Samuel. On War and Writing. Chicago and London: The University of Chicago Press, 2018.

Kalning, Pamela. Kriegslehren in deutschsprachigen Texten um 1400: Seffner, Rothe, Wittenswiler; mit einem Abdruck der Wiener Handschrift von Seffners "Ler von dem streitten" (War Lessons in German-Language Texts from ca. 1400: Seffner, Rothe, Wittenwiler; with a Reprint of the Viennese Manuscript of Seffner's "Ler von dem streitten.") Studien und Texte zum Mittelalter und zur frühen Neuzeit, 9. Münster, New York, et al.: Waxmann, 2006.

Koistinen, Paul. Military-Industrial Complex: A Historical Perspective. New York: Praeger, 1980.

Konstan, David and Kurt A. Raaflaub (Eds.) Epic and History. The Ancient World: Comparative Histories. Maldon, MA, and Oxford: Blackwell, 2010. 
Krimmer, Elisabeth. The Representation of War in German Literature: From 1800 to the Present. New York: Cambridge University Press, 2010.

Laude, Corinna. "Daz in swindelt in den sinnen ...": Die Poetik der Perspektive bei Heinrich Wittenwiler und Giovanni Boccaccio (...: The Poetics of Perspectives in Heinrich Wittenwiler and Giovanni Boccaccio). Philologische Studien und Quellen, 173. Berlin: Erich Schmidt, 2002.

Ludwig Jansen, Katherine. Peace and Penance in Late Medieval Italy. Princeton, NJ, and Oxford: Princeton University Press, 2018.

Lungershausen, Gerrit. Weltkrieg mit Worten: Kriegsprosa im Dritten Reich 1933 bis 1940 (World War with Words: War Prose in the Third Reich 1933 to 1940). Wiesbaden: J. B. Metzler, 2017.

Lutz, Eckart Conrad. Spiritualis fornicatio: Heinrich Wittenwiler, seine Welt und sein 'Ring' (...: Heinrich Wittenwiler, His World, and His 'Ring'). Konstanzer Geschichts- und Rechtsquellen, 32. Sigmaringen: J. Thorbecke Verlag, 1990.

Mackasare, Manuel. Krieg und Literatur (War and Literature.) Akademische Blätter. Retrieved from: https://aka-blaetter.de/krieg-und-literatur/.

Maroszová, Jana. Denn die Zeit ist nahe: Eschatologie in Grimmelshausens Simplicianischen Schriften: Zeit und Figuren der Offenbarung (The Time is Near: Eschatology in Grimmelshausen's Simplianische Schriften: Time and Figures in the Revelation). Beihefte zu Simpliciana, 8. Bern: Peter Lang, 2013.

May, Larry (Ed.) The Cambridge Handbook of the Just War. Cambridge Handbooks in Philosophy. Cambridge: Cambridge University Press, 2018.

Meid, Volker. Grimmelshausen: Leben, Werk, Wirkung (Grimmelshausen: Life, Work, Reception). Stuttgart: Philipp Reclam jun., 2011.

Murdoch, Brian (Ed.) German Literature and the First World War: The Anti-War Tradition: Collected Essays. Ashgate Studies in First World War History. Farnham, Surrey: Ashgate Publishing Limited; Burlington, VT: Ashgate Publishing Company, 2015.

Remarque, Erich Maria. Im Westen nichts Neues (All Quiet on the Western Front). Berlin: Propyläen Verlag, 1929.

Rogers, Clifford J. "Agincourt, Battle of." The Oxford Encyclopedia of Medieval Warfare and Military Technology, edited by Clifford J. Rogers. Volume 1. Oxford: Oxford University Press, 2010, 7-10.

Rogge, Jörg (Ed.) Kriegserfahrungen erzählen: Geschichts- und literaturwissenschaftliche Perspektiven (To Narrate War Experiences: Historial and Literary-Historical Perspectives). Mainzer historische Kulturwissenschaften, 37. Bielefeld: transcript, 2017.

Rohr, Christian, Ursula Bieber and Katharina Zeppezauer-Wachauer (Eds.) Krisen, Kriege, Katastrophen: Zum Umgang mit Angst und Bedrohung im Mittelalter (Crises, Wars, Catastrophes: On the Treatment of Fright and Threats in the Middle Ages). Interdisziplinäre Beiträge zu Mittelalter und Früher Neuzeit, 3. Heidelberg: Universitätsverlag Winter, 2018.

Rose, Mark H. and Roger Biles (Eds.) The President and American Capitalism since 1945. Gainesville, FL: University Press of Florida, 2017.

Russell, Frederick H. The Just War in the Middle Ages. Cambridge: Cambridge University Press, 1975. 
Vol. 9, No. 2 Classen: The Horrors of War in the History of of German Literature ...

Schneider, Thomas F. (Ed.) Erich Maria Remarque: Leben, Werk und weltweite Wirkung (Erich Maria Remarque: Life, Work, and Global Reception). Erich-Maria-RemarqueJahrbuch, 8. Osnabrück: Rasch, 1998.

Schneider, Thomas. Unabhängigkeit, Toleranz, Humor: Independence, Tolerance, Humor: Erich Maria Remarque 1898-1970. Osnabrück: Universitäts-Verlag Rasch, 2001.

Schöning Matthias (Ed.) Ernst Jünger-Handbuch: Leben - Werk - Wirkung (Ernst Jünger Handbook: Life - Work - Reception). Stuttgart and Weimar: Verlag J. B. Metzler, 2014.

Stammler, Wolfgang F. et al. (Eds.) Erasmus of Rotterdam, Über Krieg und Frieden (On War and Peace). Bibliothek historischer Denkwürdigkeiten. Essen: Alcorde Verlag, 2018.

Vecchiato, Daniele. Krieg und Frieden in der Literatur; zu Zeugnissen aus Literatur und Publizistik der letzten drei Jahrhunderte (War and Peace in Literature: On Witnesses in Literature and Journalism from the Last Three Centuries). Berlin: "Helle Panke" e.V. Rosa-Luxemburg-Stiftung Berlin 2009.

Walker, Gregg B. (Ed.) The Military Industrial Complex: Eisenhower's Warning Three Decades Later. American University Studies/Series 10/Political Science, 32. New York, San Francisco, et al.: Peter Lang, 1992.

Werkner, Ines-Jacqueline. Gerechter Frieden: Das fortwährende Dilemma militärischer Gewalt (Just Peace: The Continuous Dilemma of Military Violence). Perspektiven. Essays aus der FEST, 1. Bielefeld: transcript-Verlag, 2018.

Wittenwiler, Heinrich. Der Ring: Text - Übersetzung - Kommentar (The Ring: Text Translation - Commentary.) Edited by Werner Röcke. Berlin and Boston: Walter de Gruyter, 2012. 